This article is (c) Emerald Group Publishing and permission has been granted for this version to appear here (https://dspace.lib.cranfield.ac.uk/index.jsp). Emerald does not grant permission for this article to be further copied/distributed or hosted elsewhere without the express permission from Emerald Group Publishing Limited.

www.emeraldinsight.com

\title{
Towards a theory of supply chain alignment enablers: a systematic literature review
}

\begin{abstract}
Purpose - The importance of supply chain alignment has been discussed since the birth of Supply Chain Management (SCM). Yet it remains a major challenge for supply chains. This paper aims to systematically review the cross disciplinary literature on supply chain alignment in order to identify, and develop constructs for enablers to alignment, and an associated set of hypotheses.
\end{abstract}

Design/methodology/approach - A systematic approach has been taken to the literature review which ensures it is auditable and repeatable. The selection criteria are clearly aligned with the review question ensuring all literature pertinent to the question is identified and reviewed. Relevant information is extracted from the selected papers and synthesised into a set of hypotheses.

Findings - Six main constructs for the enablers of alignment are identified and defined: organisational structure, internal relational behaviour, customer relational behaviour, top management support, information sharing and business performance measurement system. While the literature is disparate, across different disciplines there is good support for these enablers. The relationships between supply chain alignment and shareholder and customer value are also argued with the support of the literature. Though each of the enablers is argued to positively affect shareholder and customer value, their interactions with each other are not well supported in the literature, either theoretically or empirically, and therefore this could be an area for further research.

Research/practical implications - While the hypotheses remain theoretical, it is now possible to test them and understand the relative significance of the various enablers to alignment. Further, the significance of shareholder and customer alignment on the delivery of shareholder and customer value can be examined, thus moving towards a theory of supply chain alignment. This is needed since in practice companies are struggling with supply chain alignment.

Originality/value - The existing literature on supply chain alignment is disparate and multidisciplinary as our descriptive analysis shows, with 72 papers published in 43 different journals. Moreover, most of the papers focus on particular enablers, while this paper brings together six key enablers from the literature to produce a set of hypotheses.

Keywords Supply chain, Alignment, Enablers, Inhibitors, Shareholder value, Customer value 


\section{Introduction}

A supply chain consists of a chain of suppliers and customers aiming to provide a product or service to the end customers. Alignment within a supply chain is an emerging and important issue. Gattorna (1998) suggests that “there must be alignment between each firm's supply chain strategy and those of its supply chain partners, both internal and external". Thus supply chain alignment results in a fit in terms of objectives, structures and processes within and between different functions and members in a supply chain. The need for supply chain alignment is indisputable. Houlihan (1985) suggested that SCM is about addressing the imbalances due to conflicting objectives in marketing, sales, manufacturing, and distribution by managing the trade-offs between supply policies, economics of manufacturing and complexity. In response to issues of this nature Gattorna proposes a four-stage framework for strategic alignment (Gattorna and Walters, 1996; Gattorna, 1998, 2009) where supply chain strategy is developed to meet the requirements of customer segments, and is supported by the right culture and leadership style, aligned with four logics (based on Carl Jung's theory).

In particular, there is a need to achieve shareholder alignment so that functional strategies and business processes used to deliver them are compatible with business strategy and shareholder expectations, such as revenue growth, working capital efficiency, operating cost reduction and fixed capital efficiency (Christopher and Ryals, 1999). This is because poor business performance is often caused by firms' failure to align internal supply chain processes with strategic goals (Tamas, 2000).

In addition to shareholder alignment, the alignment with customers is equally critical. Since every member in a supply chain tends to maximise their own interests, optimal decisions made by one supply chain member may cause delivery delays and excessive inventories in another part of the supply chain (Lee, 2004). Ideally everyone in the supply chain should have the same objective - to deliver the best value to the end consumers. That means a supply chain has to be aligned to deliver customer value, measured in terms of customer perceived benefits gained from a product/service compared to the cost of purchase (Johnson and Scholes, 1999). The importance of customer alignment is supported by the customer-orientation literature (Anderson and Narus, 1990; Jeong and Hong, 2007) and the need for aligning the demand creation processes with the demand fulfilment or SCM processes to achieve customer responsiveness (Godsell et al., 2006). The relationship between shareholder and customer alignment in terms of the extent to which they reinforce each other, or indeed are conflicting, is however not clearly explained in the supply chain literature.

Despite general agreement on the need for supply chain alignment to achieve shareholder and customer value, SCM research and practice lacks knowledge on how exactly such an alignment can be achieved and what performance implications it has (Baier et al., 2008). A survey carried out by Tamas (2000) found that only $13 \%$ of the 80 supply chain executives questioned believed that their companies' supply chain practices are actually fully aligned with their business unit strategies. In reality, the ability to create "seamless" or "boundary-less" connections in a supply chain (Christopher et al., 2004) is hard to achieve. Many supply chain experts agree that internal alignment is still an unresolved issue and can be more difficult than building external alliances. Indeed, breaking down silos between sales/marketing and the operations/supply chain functions is still a pervasive problem (Beth et al., 2003; Pagell, 2004; van Hoek and Mitchell, 2006). This strongly suggests the need to identify and understand enablers of supply chain alignment.

Alignment or fit has been identified as an essential antecedent of firm performance by the major business and management disciplines including strategy literature (Powell, 1992; Venkatraman, 1989), organisation literature (Nadler and Tushman, 1988; Kathuria et al., 2007), information system literature (Brown and Magill, 1994; Luftman and Brier, 1999) and manufacturing strategy literature 
(Skinner, 1969; Wheelwright, 1984; McAdam and Brown, 2001). However, at the moment the literature on supply chain alignment is fragmented and largely theoretical in nature. Given the emergent and multi-disciplinary nature of such a literature, the development of both theory and practice of supply chain alignment would benefit from a theoretical framework which "poses a degree of order on a disorderly mélange" (Starbuck, 2006). To do this, a systematic literature review (SLR) of relevant literature will allow us to perform a meta-analysis of the theories and empirical evidence. Indeed Starbuck (p. 96) believes that, as demonstrated by Kelley and Thibaut (1954), "a good literature review makes sense out of nonsense".

Through an SLR this paper aims to identify enablers of supply chain alignment, develop constructs for them and develop a set of hypotheses which address the complex relationships between shareholder alignment/value and customer alignment/value. Through the SLR, the paper aims to answer two crucial questions: (1) What are the enablers for customer and shareholder alignment? (2) How can they be defined and how do they affect alignment and ultimately customer and shareholder value? Answers to these questions will enhance the knowledge about how exactly supply chain alignment can be achieved and its performance implications (Baier et al., 2008). Since alignment is a research topic shared by many disciplines, the SLR includes cross disciplinary literature on supply chain alignment. This paper begins with a description of the SLR methodology used in this study. The results follow with a descriptive analysis of the papers selected for review and a discussion of the emerging themes from the literature which constitute the enablers of supply chain alignment. Based on a reductionist approach, this paper further develops a set of hypotheses relating supply chain alignment enablers to shareholder and customer alignment and value. Finally the implications and limitations of this paper are discussed in the conclusions.

\section{Method}

To overcome the perceived weaknesses of a narrative review (Tranfield, et al., 2003) this study adopted a systematic or evidence-informed approach based on the five-step approach outlined by Denyer and Tranfield (2009). The five steps as illustrated in

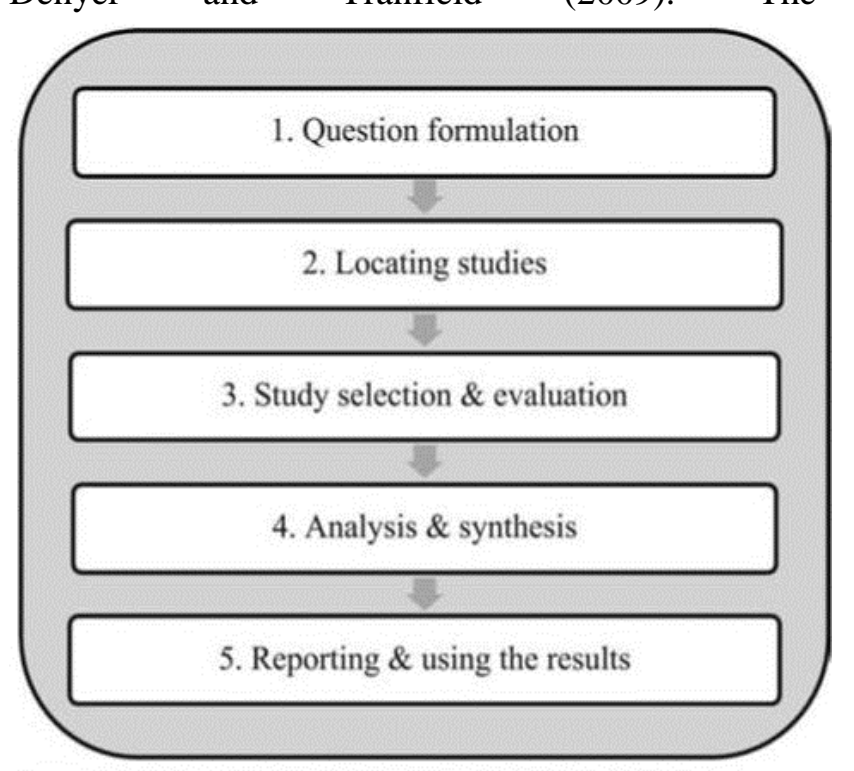

Source: Adapted from Denyer and Tranfield (2009)

include: question formulation, locating studies, study selection and evaluation, analysis and synthesis, and finally reporting and using the results. Each step will now be discussed in turn.

Figure 1: Overview of the 5-step systematic literature review process (Denyer and Tranfield, 2009) 


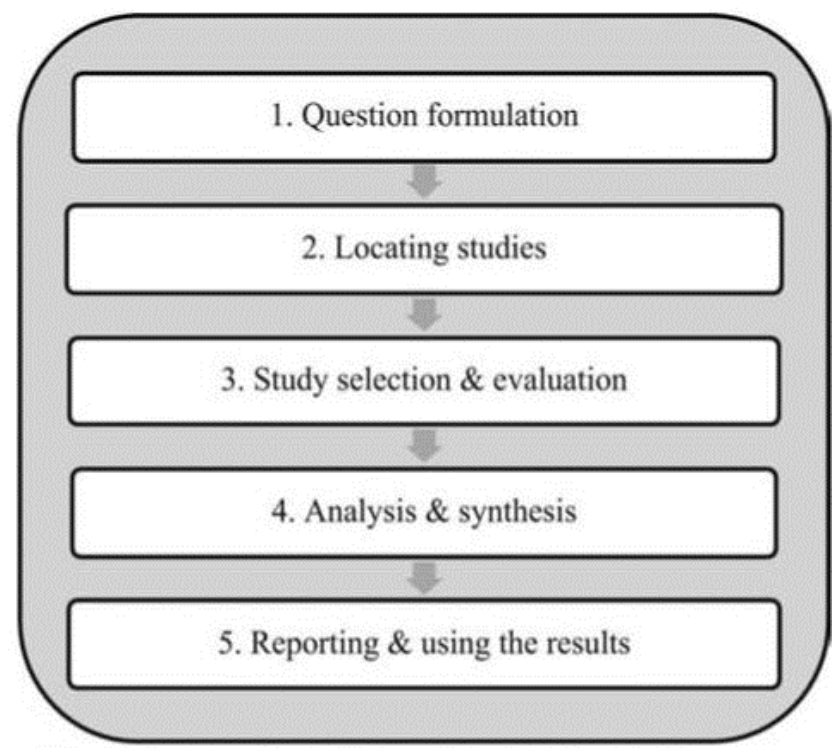

Source: Adapted from Denyer and Tranfield (2009)

\subsection{Question formulation}

A clear research question is critical to provide the focus and direction for any research. It is particularly important for a systematic literature review (SLR) and hence a panel is formed to help to review and refine this question. The panel for this study included five different stakeholders, each with a different area of expertise relevant to the study, including: customer driven supply chain strategy, shareholder value, manufacturing strategy and quantitative methods.

The primary question that this study seeks to address is:

- What are the enablers to customer and shareholder alignment?

Supported by two supplementary questions:

- How can they be defined?

- How do they effect alignment, and ultimately customer and shareholder value?

\subsection{Locating studies}

The next step is to locate the relevant studies. There are two key decisions to make at this stage of the review; the search engine and search strings. After consultation with a database expert with significant experience of supporting faculty in conducting SLRs, two search engines were chosen: ABI Inform ProQuest and EBSCO host. Given that the context for the study is the supply chain, these were identified as the databases with the best coverage for this field.

The initial search terms used were quite broad to ensure that papers adopting alternative nomenclature were identified. Two alternative sets of search strings were used as summarised in Table 1 and resulted in the identification of 1,944 papers. The search was limited to scholarly articles, published between January 1976 and December 2010. The initial study took place as part of an Innovative Manufacturing Research Council project (IMRC 40) exploring the alignment and integration of marketing and supply chain strategy in late 2007 and this was later updated.

Table 1: Search strings and resultant number of papers

\section{Search Actual Search Strings}




\begin{tabular}{|l|l|r|}
\hline 1 & $\begin{array}{l}\text { (enabl* OR facilitat* OR inihibit* OR barrier* OR prevent* OR constrain*) } \\
\text { AND (customer* OR shareholder*) AND (supply chain* OR demand chain* } \\
\text { OR value chain* OR supply network* OR manufactur*) AND (align* OR } \\
\text { integrat* OR coordinat* OR fit* OR link* OR value*) }\end{array}$ & 1,393 \\
\hline 2 & $\begin{array}{l}\text { (enabl* OR facilitat* OR inihibit* OR barrier* OR prevent* OR constrain*) } \\
\text { AND (customer* OR shareholder*) AND (value*) AND (strateg*) AND } \\
\text { (deploy* OR formulat* OR process* OR plan* OR align* OR integrat* OR } \\
\text { coordinat* OR fit* OR link*) }\end{array}$ & 551 \\
\hline Total & \multicolumn{1}{|l|}{ O44 } \\
\hline
\end{tabular}

\subsection{Study selection and evaluation}

Given the breadth and fragmentation of the field, a decision was taken not to try and reduce the number of articles further by refining the search strings. Instead a decision was made to review the title, journal and abstracts for relevance. The selection criteria used were:

- Alignment - the paper had to be relevant to process alignment and strategic alignment with the objective of maximising shareholder and customer value

- Supply chain - whilst a broad topic, the papers had to focus on relationships and strategy alignment

- Language - the paper had to be written in English

- Journal type - top quality, double-blind peer reviewed journals

An initial sample of 50 abstracts was reviewed by two reviewers to check for inter-code reliability. The inclusion or exclusion of the abstracts was checked against the general criteria, results compared and discussed, and issues of disagreement resolved (Miles and Huberman, 1994). This exercise reduced the number of potential papers to 253 .

At this stage a more robust set of quality criteria was then applied to the full text review of the 253 papers. Two sets of criteria were applied: subject matter selection and quality criteria. The subject matter criteria varied by paper type and are summarised in Table 2 .

Table 2: Subject matter selection criteria

\begin{tabular}{|l|l|}
\hline Paper Type & The papers must contain... \\
\hline Conceptual / theoretical & Enablers (or inhibitors) and arguments in support \\
\hline Empirical & Enablers (or inhibitors) and empirical evidence in support \\
\hline Methodological & Causal relationships between enablers (or inhibitors) \\
\hline
\end{tabular}

The quality criteria applied were based on the standard criteria developed for SLR at Cranfield University. As illustrated in Table 3 they include: contribution, theory, methodology and data analysis.

Table 3: Quality assessment criteria (Cranfield University SLR protocol)

\begin{tabular}{|l|l|}
\hline Elements to & Level \\
\hline
\end{tabular}




\begin{tabular}{|c|c|c|c|c|c|}
\hline consider & 0 - Absence & 1 - Low & 2 - Medium & 3 - High & Not Applicable \\
\hline Contribution & $\begin{array}{l}\text { The article does } \\
\text { not provide } \\
\text { enough } \\
\text { information to } \\
\text { assess this criteria }\end{array}$ & $\begin{array}{l}\text { The paper adds } \\
\text { little to the body } \\
\text { of knowledge in } \\
\text { this area. }\end{array}$ & $\begin{array}{l}\text { The paper adds a } \\
\text { contribution of } \\
\text { limited importance } \\
\text { to the body of } \\
\text { knowledge. }\end{array}$ & $\begin{array}{l}\text { The paper adds a } \\
\text { highly significant } \\
\text { contribution to the } \\
\text { body of } \\
\text { knowledge. }\end{array}$ & $\begin{array}{c}\text { This element is } \\
\text { not applicable to } \\
\text { this paper }\end{array}$ \\
\hline Theory & $\begin{array}{l}\text { The article does } \\
\text { not provide } \\
\text { enough } \\
\text { information to } \\
\text { asses this criteria }\end{array}$ & $\begin{array}{l}\text { Literature review } \\
\text { is inadequate. }\end{array}$ & $\begin{array}{l}\text { Literature review } \\
\text { is acceptable. }\end{array}$ & $\begin{array}{c}\text { Excellent } \\
\text { literature review. } \\
\text { In domain of } \\
\text { theory. }\end{array}$ & $\begin{array}{c}\text { This element is } \\
\text { not applicable to } \\
\text { this paper }\end{array}$ \\
\hline Methodology & $\begin{array}{l}\text { The article does } \\
\text { not provide } \\
\text { enough } \\
\text { information to } \\
\text { asses this criteria }\end{array}$ & $\begin{array}{l}\text { Not fully } \\
\text { explained, difficult } \\
\text { to replicate. }\end{array}$ & $\begin{array}{l}\text { Acceptable } \\
\text { explanation and } \\
\text { replicability of } \\
\text { methodology. }\end{array}$ & $\begin{array}{l}\text { Clear explanation } \\
\text { of methodology } \\
\text { and excellent } \\
\text { records for audit } \\
\text { trail. }\end{array}$ & $\begin{array}{c}\text { This element is } \\
\text { not applicable to } \\
\text { this paper }\end{array}$ \\
\hline Analysis & $\begin{array}{l}\text { The article does } \\
\text { not provide } \\
\text { enough } \\
\text { information to } \\
\text { asses this criteria }\end{array}$ & $\begin{array}{l}\text { Data sample is } \\
\text { insufficient. } \\
\text { Weak connection } \\
\text { between data and } \\
\text { story. }\end{array}$ & $\begin{array}{l}\text { Appropriate data } \\
\text { sample. Adequate } \\
\text { analysis but weak } \\
\text { explanation. }\end{array}$ & $\begin{array}{l}\text { Adequate data } \\
\text { sample, results } \\
\text { support theoretical } \\
\text { arguments. Good } \\
\text { explanations. }\end{array}$ & $\begin{array}{c}\text { This element is } \\
\text { not applicable to } \\
\text { this paper }\end{array}$ \\
\hline
\end{tabular}

For a full paper to be accepted, it had to meet the subject matter selection criteria and satisfy at least one of the quality criteria in the 'high band'. Similarly to the abstract read, initial samples of papers were reviewed by the two reviewers. The inclusion or exclusion of the papers was checked against the two sets of criteria, results compared and discussed, and issues of disagreement resolved (Miles and Huberman, 1994). Application of these criteria reduced the resultant number of full papers for analysis and synthesis to 72 .

\subsection{Analysis and synthesis}

Each paper was analysed for both its descriptive and thematic content by the 2 reviewers, who both reviewed a sizeable sample of the papers discussing their findings, before splitting the papers between them. This ensured they were interpreting the content in a similar way. The descriptive analysis was more deductive in nature, and focused on the categorisation of papers by year, ABS code, country, methodology and industry.

The thematic analysis identifies and categorises emerging enablers to supply chain alignment. Its purpose was to identify the emerging constructs around the enablers to supply chain alignment. A more inductive approach was taken. Enabling factors were identified, and then grouped into a series of enabling constructs. Given that the initial study took place in 2007, the constructs were updated to include more relevant references. These were identified through a much simplified search of papers focused on supply chain alignment. This was deemed the most appropriate means to update the study as firstly, the incidence of papers was relatively low and secondly to avoid undermining the integrity of the original study. These papers are easily identifiable as they have references with a date after 2006.

\subsection{Reporting and using the results}

This paper is the first formal presentation of the results to an academic audience, though already presented to a practitioner workshop of 36 practitioners, by whom the results were well received. The 
remainder of this paper is dedicated to reporting these results; descriptively, thematically and as a theoretical framework for application to both academia and practice.

\section{Descriptive results: characterising the supply chain alignment literature}

The 72 papers identified through the SLR are analysed in this section with respect to the publication year, methodology, journal and sector studied, in order to understand the trends in this body of literature relevant to supply chain alignment and the associated enablers. 
Figure 2 Analysis of papers according to year of publication and methodology

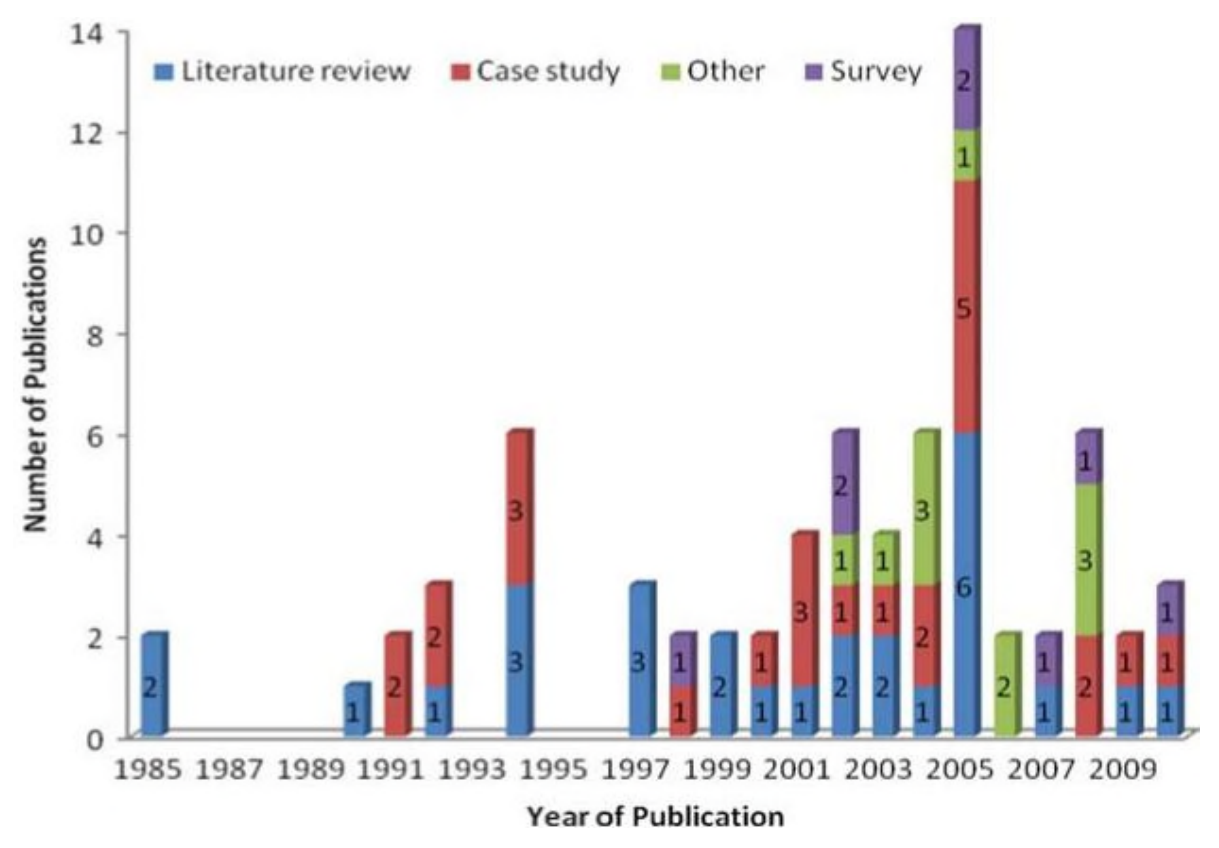

The papers were published between 1985 and 2010 with sporadic publications in the 80's and 90's as illustrated in Figure 2. Through the late 90's and into the early 2000's the number of annual publications rose, peaking sharply in 2005 with 14 papers published. From 2000 through to 2010, 51 articles were published, which constitutes about $70 \%$ of the papers in this study. This indicates an increasing interest in supply chain alignment and approaches to achieving it. This could be fuelled by the persistent need to break down functional silos between sales/marketing and the operations/supply chain (Beth et al., 2003, Pagell, 2004; van Hoek and Mitchell, 2006).

The case study (35\% of papers) and literature review (39\% of papers) are used to a similar extent and are clearly the most frequently used methodologies, accounting for almost three quarters of the publications. Further they tend to be used consistently over the years of publication. However, the literature review is the most popular method used for this topic as researchers struggle to develop theory from existing literature. Only in recent years have there been some empirical case studies and surveys, indicating the infancy stage of the theoretical development process. Our paper aims to use a systematic approach to the literature review that is able to identify and synthesise this body of literature. This is no easy task because it is a wide ranging body of literature involving many disciplines. As evidenced by the analysis of papers by journal and the Association of Business School (ABS) categories (shown in Table 4), it has been published in a wide range of journals.

The 72 papers identified by the literature review were published in 43 different journals. Indeed $63 \%$ of the journals had only one article published on this topic. This emphasises that this topic has wide ranging relevance across many different disciplines, as might be expected. Alignment, after all, is seeking to develop consistency between all the business functions. However, 55\% of the papers were published in journals within the Operations and Technology category, with many of these journals focussing on supply chain and logistics. In fact the International Journal of Physical Distribution and Logistics Management (IJPDLM) publishing the most papers (6). This reflects the fact that many of the functions which require alignment, to deliver either shareholder or customer value, are within the supply chain field: purchasing, manufacturing, logistics and operations planning. Moreover, supply chain management is often defined in terms of alignment of these functions. For example Lambert et al., (1998) cite a definition of supply chain management originally defined in 
1994 and refined in 1998 by the members of the Global Supply Chain Forum: 'supply chain management is the alignment of key business processes (Plan-Source-Make-Deliver) from customer through original suppliers that provides products, services, and information that add value for customers and other stakeholders'.

Table 4 Analysis of papers according to journal and ABS category (note: the authors categorised those papers in italics)

\begin{tabular}{|c|c|c|c|}
\hline ABS Field & Journals & $\begin{array}{l}\text { No. of } \\
\text { articles }\end{array}$ & Author(Year) \\
\hline \multirow{40}{*}{$\begin{array}{l}\text { Operations \& } \\
\text { Technology }\end{array}$} & \multirow{6}{*}{$\begin{array}{l}\text { International Journal of Physical Distribution \& } \\
\text { Logistics Management }\end{array}$} & \multirow{6}{*}{6} & Halldórsson et al. (2008) \\
\hline & & & Lehtonen et al. (2005) \\
\hline & & & Barratt and Oliveira (2001) \\
\hline & & & Rich and Hines (1997) \\
\hline & & & Scott and Westbrook (1991) \\
\hline & & & Gattorna et al. (1991) \\
\hline & \multirow{5}{*}{ Supply Chain Management: An International Journal } & \multirow{5}{*}{5} & Kannan and Tan (2010) \\
\hline & & & Sha et al. (2008) \\
\hline & & & Othman and Ghani (2008) \\
\hline & & & Soosay et al. (2008) \\
\hline & & & Tracey et al. (2005) \\
\hline & \multirow{4}{*}{ International Journal of Logistics Management } & \multirow{4}{*}{4} & Sandberg (2007) \\
\hline & & & Holweg (2005) \\
\hline & & & Bagchi and Skjoett-Larsen (2003) \\
\hline & & & Barratt (2003) \\
\hline & \multirow{3}{*}{ Journal of Manufacturing Technology Management } & \multirow{3}{*}{3} & Tsinopoulos and Bell (2010) \\
\hline & & & Fassoula (2006) \\
\hline & & & Buyukozkan (2004) \\
\hline & \multirow{3}{*}{ Journal of Business Logistics } & \multirow{3}{*}{3} & Lambert et al. (2005) \\
\hline & & & Rodrigues et al. (2004) \\
\hline & & & Sabath and Whipple (2004) \\
\hline & \multirow{3}{*}{ Journal of Operations Management } & \multirow{3}{*}{3} & Petersen et al. (2005) \\
\hline & & & Childerhouse et al. (2002) \\
\hline & & & Hill and Scudder (2002) \\
\hline & \multirow{2}{*}{ International Journal of Production Economics } & \multirow{2}{*}{2} & Kauremma et al. (2009) \\
\hline & & & Kalchschmidt et al. (2003) \\
\hline & \multirow{2}{*}{$\begin{array}{l}\text { International Journal of Operations \& Production } \\
\text { Management }\end{array}$} & \multirow{2}{*}{2} & Reichhart and Holweg (2007) \\
\hline & & & Storey et al. (2005) \\
\hline & \multirow{2}{*}{ Benchmarking } & & Simatupang and Sridharan (2004) \\
\hline & & 2 & Fawcett and Cooper (2001) \\
\hline & International Journal of Physical Distribution \& & 2 & Houlihan (1985) \\
\hline & Materials Management & 2 & Jones and Riley (1985) \\
\hline & International Journal of Production Research & 1 & Campbel and Sankaranl (2005) \\
\hline & Business Process Management Journal & 1 & Harrison (1998) \\
\hline & $\begin{array}{l}\text { International Journal of Logistics: Research \& } \\
\text { Applications }\end{array}$ & 1 & Auramo et al. (2004) \\
\hline & Production Planning \& Control & 1 & Chung and Leung (2005) \\
\hline & Planning Review & 1 & Robertson and Barich (1992) \\
\hline & Performance Improvement & 1 & Maku et al. (2005) \\
\hline & $\begin{array}{l}\text { Journal of Supply Chain Management: A Global } \\
\text { Review of Purchasing \& Supply }\end{array}$ & 1 & Hartley (2000) \\
\hline & Production \& Inventory Management Journal & 1 & Lummus and Vokurka (1999) \\
\hline & The Journal of Business \& Industrial Marketing & 3 & Storbacka and Nenonen (2009) \\
\hline & The Journal of Busıness \& Industrial Marketıng & 3 & Sabath and Whipple (2004) \\
\hline & & & Campbell (1998) \\
\hline Marketing & Lournal of the Academy of Marketing Science & 2 & Esper et al. (2010) \\
\hline & Journal of the Academy of Marketıng Sclence & 2 & Woodruff (1997) \\
\hline $10(14 \%)$ & Inductrial Marketing Management & 2 & Matthyssens and Vandenbempt (2008) \\
\hline & Industrıal Marketıng Management & 2 & Christopher and Gattorna (2005) \\
\hline & Journal of Marketing & 1 & Srivastava et al. (1999) \\
\hline & Marketing Intelligence \& Planning & 1 & Groth (1994) \\
\hline & Academy of Marketing Science Review & 1 & Hoffman (2000) \\
\hline & Haryard Pusines Paview & & Heskett et al, (1994) \\
\hline & Harvard Business Review & 2 & Day and Fahey (1990) \\
\hline General & Business Review & 1 & Muratoglu (2008) \\
\hline Management & International Journal of Management & 1 & Mahmoud et al. (2005) \\
\hline $9(13 \%)$ & MIT Sloan Management Review & 1 & Burgelman and Doz (2001) \\
\hline $9(1.5 \%)$ & Management Decision & 1 & Feurer and Chaharbaghi (1994) \\
\hline & Business Horizons & 1 & Slater and Narver (1994) \\
\hline
\end{tabular}




\begin{tabular}{|c|c|c|c|}
\hline & The McKinsey Quarterly & 1 & George et al. (1994) \\
\hline \multirow{3}{*}{$\begin{array}{l}\text { Information } \\
\text { Management }\end{array}$} & \multirow{2}{*}{ Industrial Management and Data Systems } & \multirow{2}{*}{2} & Sahay (2003) \\
\hline & & & Tarn et al. (2002) \\
\hline & International Journal of Information Management & 1 & Pollalis (2003) \\
\hline \multirow{3}{*}{$6(8 \%)$} & Journal of Management Information Systems & 1 & Clemons and Weber (1994) \\
\hline & Decision Support Systems & 1 & Marquez and Blanchar (2006) \\
\hline & Information Technology and Management & 1 & Clark et al. (2001) \\
\hline \multirow{3}{*}{$\begin{array}{l}\text { Organisation \& } \\
\text { Management } \\
\text { Science } \\
3(4 \%)\end{array}$} & \multirow{2}{*}{ Decision Sciences } & \multirow{2}{*}{2} & Frohlich (2002) \\
\hline & & & Sahin and Robinson (2002) \\
\hline & Systems Research and Behavioural Science & 1 & Osterlund and Loven (2005) \\
\hline \multirow{3}{*}{$\begin{array}{l}\text { Strategy } \\
3(4 \%)\end{array}$} & Long Range Planning & 1 & Buhner (1997) \\
\hline & The Journal of Business Strategy & 1 & Nichol (1992) \\
\hline & Strategy \& Leadership & 1 & Kaplan and Norton (2004) \\
\hline $\begin{array}{l}\text { Accounting } \\
1(1 \%)\end{array}$ & Critical Perspectives on Accounting & 1 & Bourguignon (2005) \\
\hline
\end{tabular}

Considering the geographical location of the authors' affiliated institution, $49 \%$ of the papers originated from the USA, suggesting a strong interest in supply chain alignment in the USA. The UK accounts for the second largest proportion of papers at $19 \%$, and other countries account for $5 \%$ or less, with 9 countries being the origin of a single paper each.

Finally it is important to determine which industrial sectors have made a contribution to the body of knowledge on supply chain alignment. Empirical data were the bases of the findings in 34 of the papers $(47 \%)$ and these data were collected from four sectors: retail, manufacturing, airline and service industries. Six publications studied both the retail and the manufacturing sectors and these were counted against both. The vast majority of the empirical papers $(91 \%)$ studied retail and/or manufacturing sectors while only four papers considered airline and service sectors. This is entirely consistent with the earlier observation that $55 \%$ of the papers are published in operations journals with an emphasis on supply chain management..

\section{Thematic results: understanding the enablers}

The SLR has identified six major enablers of alignment which are defined and explained in this section (see Table 5 for a summary of the constructs and supporting literature).

Table 5: Constructs and indicators together with supporting references, for the enablers to supply chain alignment.

\begin{tabular}{|c|c|c|c|}
\hline \multirow{2}{*}{$\begin{array}{l}\text { Enabler } \\
\text { Constructs }\end{array}$} & \multicolumn{2}{|c|}{ Indicators } & \multirow[t]{2}{*}{ Supporting references } \\
\hline & \# & Description & \\
\hline \multirow[t]{5}{*}{$\begin{array}{l}\text { Organisational } \\
\text { structure (OS) }\end{array}$} & OS1 & Control spans & $\begin{array}{l}\text { Aldrich and Herker, 1977; Ettlie and Stoll, 1990; Sussman and } \\
\text { Dean, 1992; Clark et al., 2001; Monczka et al., } 2009\end{array}$ \\
\hline & OS2 & Business process owner & $\begin{array}{l}\text { Davenport, 1993; Hammer and Champy, 1993; George et al., } \\
\text { 1994; Earl, 2002; Karapetrovic and Willborn, 2002; Lewis and } \\
\text { Slack, } 2003\end{array}$ \\
\hline & OS3 & $\begin{array}{l}\text { Cross-functional knowledge } \\
\text { flow }\end{array}$ & Fawcett and Magnan, 2002; Eng, 2006; Esper et al. 2010 \\
\hline & OS4 & $\begin{array}{l}\text { Process-oriented } \\
\text { organisation }\end{array}$ & Kalchschmidt et al., 2003; Lambert et al., 2005 \\
\hline & OS5 & Inter-departmental activities & $\begin{array}{l}\text { Slater and Narver, 1994; Ellinger, 2000; Danese and Romano, } \\
\text { 2004; Esper } \text { et al. } 2010\end{array}$ \\
\hline \multirow{3}{*}{$\begin{array}{l}\text { Internal } \\
\text { relational } \\
\text { behaviour } \\
\text { (IR) }\end{array}$} & IR1 & Cross-functional team & $\begin{array}{l}\text { Wheelwright and Clark, 1992; Pagell, 2004; Yasin et al., 2005; } \\
\text { Fassoula, } 2006\end{array}$ \\
\hline & IR2 & Mutual understanding & Kahn and Mentzer, 1996; O'Leary-Kelly and Flores, 2002 \\
\hline & IR3 & Joint problem solving & Dean, 1992; Khan, 1996; Ellinger, 2000 \\
\hline
\end{tabular}




\begin{tabular}{|c|c|c|c|}
\hline & IR4 & Joint planning & Anderson and Narus, 1990; Chen and Paulraj., 2004 \\
\hline \multirow{5}{*}{$\begin{array}{l}\text { Customer } \\
\text { relational } \\
\text { behaviour } \\
(\mathrm{CR})\end{array}$} & CR1 & Goal sharing & Barratt and Oliviera, 2001; Sabath and Wipple, 2004 \\
\hline & CR2 & Cost sharing & $\begin{array}{l}\text { Campbell, 1998; Cachon and Lariviere, 2005; Reichhart and } \\
\text { Holweg, 2007; Sha et al.2008; Soosay et al. } 2008\end{array}$ \\
\hline & CR3 & Profit sharing & Fawcett and Cooper, 2001; Simatupang and Sridharan, 2004 \\
\hline & CR4 & Joint problem solving & Ellinger, 2000; Rich and Hines, 1997 \\
\hline & CR5 & Joint planning & $\begin{array}{l}\text { Jones and Riley, 1985; Anderson and Narus, 1990; Auramo et al., } \\
\text { 2004; Simatupang and Sridharan, 2004; Chen and Paulraj., 2004, } \\
\text { Reichhart and Holweg, 2007; Soosay et a. } 2008\end{array}$ \\
\hline \multirow{6}{*}{$\begin{array}{l}\text { Top } \\
\text { management } \\
\text { support (TS) }\end{array}$} & TS1 & Listen to employees & Heskett et al., 1994; Carrilat et al., 2004 \\
\hline & TS2 & Management involvement & $\begin{array}{l}\text { Nichol, 1992; Wheelwright and Clark, 1992; Sussman and Dean, } \\
\text { 1992; Gerbing et al., 1994; Luftman, 1998; Lee, 2004; Fawcett et } \\
\text { al., 2006; Sandberg, } 2007\end{array}$ \\
\hline & TS3 & Provisions of resources & Buhner, 1997; Kaplan and Norton, 2004; Storey et al., 2005 \\
\hline & TS4 & Provisions of finance & Buhner, 1997; Kaplan and Norton, 2004; Storey et al., 2005 \\
\hline & TS5 & $\begin{array}{l}\text { Recognise importance of } \\
\text { SCM }\end{array}$ & Christopher, 1998; Fassoula, 2006 \\
\hline & TS6 & $\begin{array}{l}\text { Understand supply chain } \\
\text { capabilities }\end{array}$ & $\begin{array}{l}\text { Srivastava et al., 1999; Kim, 2006; Soosay et al., 2008; } \\
\text { Tsinopoulos and Bell, } 2010\end{array}$ \\
\hline \multirow[t]{5}{*}{$\begin{array}{l}\text { Information } \\
\text { sharing (IS) }\end{array}$} & IS1 & Share relevant information & $\begin{array}{l}\text { Bowersox and Daugherty, 1995; Lee et al., 1997; Frochlich and } \\
\text { Westbrook, 2001; Soosay et al. } 2008\end{array}$ \\
\hline & IS2 & Share accurate information & $\begin{array}{l}\text { Bourland et al., 1996; Lee and Whang, 2000; Li and Lin, 2006; } \\
\text { Lehtonen } \text { et al., 2005; Kannan and Tan, } 2010\end{array}$ \\
\hline & IS3 & Share sufficient information & Huang et al., 2003 \\
\hline & IS4 & Timely information sharing & $\begin{array}{l}\text { Bourland et al., 1996; Lee and Whang, 2000; Lehtonen et al., } \\
\text { 2005; Osterlund and Loven, 2005; Kannan and Tan (2010) }\end{array}$ \\
\hline & IS5 & $\begin{array}{l}\text { Knowledge to use shared } \\
\text { information }\end{array}$ & Sahin and Robinson, 2002 \\
\hline \multirow{4}{*}{$\begin{array}{l}\text { Business } \\
\text { performance } \\
\text { measurement } \\
\text { system (PM) }\end{array}$} & PM1 & $\begin{array}{l}\text { Linked to strategic } \\
\text { objectives }\end{array}$ & $\begin{array}{l}\text { Maskell, 1991; Schmenner and Vollmann, 1994; Toni and } \\
\text { Tonchia, 1996; O'Mara et al.,1998; Neely, } 2002\end{array}$ \\
\hline & PM2 & Shared metrics & $\begin{array}{l}\text { Fawcett and Cooper, 2001; Robson, 2004; Chenhall, 2005; } \\
\text { Muratoglu, } 2008\end{array}$ \\
\hline & PM3 & $\begin{array}{l}\text { Shared targets, incentives } \\
\text { and rewards }\end{array}$ & $\begin{array}{l}\text { Morash and Clinton, 1998; Burgelman and Doz, 2001; Kannan } \\
\text { and Tan, 2010; Lee, 2004; Simatupang and Sridharan, 2004; } \\
\text { Yasin et al., 2005; Muratoglu, } 2008\end{array}$ \\
\hline & PM4 & Timely reporting & Wilcox and Bourne, 2003; Franco-Santos et al. 2004 \\
\hline
\end{tabular}

\subsection{Organisational structure (OS)}

The organisation literature advocates that organisation structure, in terms of formalisation, centralisation, and hierarchy, have to be aligned with strategy and the environment (Thompson, 1976; Lawrence and Lorsch, 1976). However, these generic features are not suitable for describing the process-oriented organisation structure required to achieve alignment across functions (Lambert et al., 2005). The SLR identified five characteristics of an organisational structure (labelled OS1...OS5) required for supply chain alignment and summarised in Table 5.

For effective alignment, organisational structure (OS) must be able to accommodate the evolving interdependencies among new and existing businesses (Burgelman and Doz, 2001). In order to break down barriers among functional departments there is a need to assign a business process owner (OS2) that has overall responsibility and accountability for the delivery of customer value from the process. 
Process owners act as integrators whose role is to stimulate operational units to pursue complex strategic integration (Burgelman and Doz, 2001). The need for process owners with adequate authority to influence multiple functions has been recognised in operations management, quality management and business reengineering, and information system literature (Davenport, 1993; Earl, 2002; Karapetrovic and Willborn, 2002; Hammer and Champy, 1993; Lewis and Slack, 2003). The influence of other functions cannot be achieved without providing the process owner with a wider span of control (OS1) or boundary spanning width (Aldrich and Herker, 1977; Ettlie and Stoll, 1990; Sussman and Dean, 1992) and supply chain literature (Clark et al., 2001; Monczka et al., 2009). However, there is also a need to improve cross-functional knowledge (OS3) to create mutual understanding and an overview of the business processes which actually deliver value to the customers (Eng, 2006; Fawcett and Magnan, 2002). Also, cross-functional knowledge (OS3) will be improved once the focal firm is able to enable inter-departmental activity (OS5) (Danese and Romano, 2004; Ellinger, 2000; Esper et al., 2010). Finally, a process-oriented organisation structure (OS4) is needed to ensure consistency between structure and adopted solutions to meet customer needs (Kalchschmidt et al., 2003)

\subsection{Internal relational behaviour (IR)}

Internal relational behaviour (IR) refers to activities and manners in which these activities are performed within an organisation to facilitate the process of building up and maintaining customer relationships. It is similar to the concept of intra-organisational connectedness which refers to the degree of formal and informal direct contacts among employees across departments (Jaworski and Kohli, 1993). Internal relational behaviour is characterised by cross-functional team (IR1), mutual understanding (IR2), joint problem-solving (IR3), and joint planning (IR4). The benefits of crossfunctional teams have been widely recognised (Fassoula, 2006). The use of cross-functional teams is found to enable strategic alignment of account systems (Yasin et al., 2005). To encourage crossfunctional team working, a cross-departmental reward system may be used (Yasin et al., 2005). Cross-functional activities often improve mutual understanding. The existence of different goals within an organisation inhibits internal collaboration (Sabath and Whipple, 2004). Alignment of internal relational behaviour is essential to achieve mutually accepted outcomes (Pagell, 2004; O'Leary-Kelly and Flores, 2002). The lack of common terminology for operations-focused and customer-facing activities will generate misunderstanding and inhibit internal collaboration (Sabath and Whipple, 2004). The importance of joint problem-solving (Ellinger, 2000) and joint planning (Chen and Paulraj, 2004; Anderson and Narus, 1990) across functional departments has also been highlighted by many studies (Sussman and Dean, 1992).

\subsection{Customer relational behaviour (CR)}

Customer relational behaviour (CR) refers to customer interactions which facilitate the process of building up and maintaining customer relationships. CR is grounded in the boundary spanning literature. Boundary spanning capability is claimed to allow organisations' processes to focus on providing superior value to external or internal customers (Day, 1994; Tracey et al., 2005). Boundary spanning activities such as market sensing, customer linking and channel bonding are essential to enhance relationships with customers. Focal firms that emphasise boundary spanning will assign roles such as liaison, task force, standing committee and integrating managers (Ettlie and Stoll, 1990; Danese and Romano, 2004; Godsell et al., 2005; George et al., 1994).

Despite its importance, existing supply chain literature fails to define the characteristics of CR. The SLR has enabled the identification of five key characteristics. Since a conflicting objective is 
often the main obstacle to customer responsiveness, the SLR suggests goal sharing (CR1), cost sharing (CR2) and profit sharing (CR3) as crucial indicators for CR in supply chains. The lack of shared goals is one of the inhibitors of collaboration in planning, forecasting and replenishment (Barratt and Oliveira, 2001; Chung and Leung, 2005). Very often any transaction or joint effort in improving a supply chain will incur costs and these costs are often unevenly distributed. Supply chain members that choose to push additional costs to other members often inhibit alignment efforts. It is also possible to devise profit-sharing contracts to share rewards (Fawcett and Cooper, 2001; Simatupang and Sridharan, 2004) and further encourage long-term collaboration. Even though the benefits of cost-sharing and profit-sharing contracts have been confirmed by numerous mathematical models in the academic literature (Simatupang and Sridharan, 2004; Reichhart and Holweg, 2007; Sha et al., 2008; Soosay et al., 2008), they are still very hard to achieve in practice, due to the asymmetric information and interests among suppliers and customers (Cachon and Lariviere, 2005).

The sharing of goals, cost and profits is only part of CR. At an operational level, focal firms need to jointly solve problems (CR4) and plan (CR5) with the customers to improve delivery performance (Auramo et al., 2004). Scott and Westbrook (1991) suggested that closer collaboration with suppliers increases supply chain integration and performance. Rich and Hines (1997) describe the use of a "supplier association" for joint problem-solving. The association extends from the focal purchasing organisation, and jointly determined supply chain improvements can be shared between the focal customer organisation and the group of suppliers. According to Rich and Hines this ensures that the efforts of each and every supplier are aligned to the changing requirements of the consumer market. As early as 1985 , Jones and Riley proposed that the key to efficiently managing a supply chain is to plan and control the inventories and activities as an integrated single entity. The use of programmes such as Collaborative Planning, Forecast and Replenishment (CPFR) can also be effective (Barratt and Oliveira, 2001; Chung and Leung, 2005). The cooperation between supply chain members (Campbell, 1998) in joint planning allows decision synchronisation (Simatupang and Sridharan, 2004; Reichhart and Holweg, 2007; Soosay et al, 2008) and collaborative value analysis (Hartley, 2000) hence ensuring alignment.

\subsection{Top management support (TS)}

Managerial commitment to SCM is required for achieving collaboration breakthrough (Akkermans et al., 1999; Lummus and Vokurka, 1998) and customer responsiveness (Storey et al., 2005). According to Fawcett et al. (2006), top management support, broad-based functional support, channel support, and infrastructure/governance support are needed to achieve the highest levels of supply chain success. To align business strategy with supply chain strategy and business processes, it is important for top management to fully support the internal communication department by being accessible, serving as a model for communication, and expecting other managers in the organisation to be strong communicators (Powers, 1996). Alignment often involves a two-way communication process between management and employees. Thus, it is essential for top management to listen to the employees (TS1) as leaders who listen (Heskett et al., 1994) will be more likely to enable change (Carrilat et al., 2004).

Top management support can also be demonstrated by participation of top management in employees' daily operations and decision-making processes. Gerbing et al. (1994) suggest that management participation has two dimensions - involvement and influence (TS2). Management involvement in goal setting, environment scanning, evaluation of the internal capabilities, generation of strategic alternatives, strategic selection and supply chain activities are critical to the success of internal and external alignment. Functional support may be demonstrated by getting middle management involved in the planning process (Nichol, 1992) as managerial influence is essential for 
aligning conflicting objectives and interests. As such, management can demonstrate visible support and involvement, by participating in key supply chain decision-making activities (Wheelwright and Clark, 1992; Sussman and Dean, 1992; Luftman, 1998; Lee, 2004; Fawcett et al., 2006).

The most obvious ways of demonstrating management support are the provisions of resources (TS3) and finance (TS4) to collaboration efforts', showing full commitment from top management (Storey et al., 2005). Another aspect of top management support is recognising the importance of SCM (TS5) as firms that do not discuss supply chain issues in the boardroom will be more internally oriented and less customer oriented. To achieve customer alignment, it is essential to demonstrate ambition and a sense of urgency and commitment from top management (Hamel and Prahalad, 1989; Bessant et al., 1994) and the embracing of SCM (Christopher, 1998; Fassoula, 2006). Awareness of supply chain (Tsinopoulos and Bell, 2010) capabilities (TS6) will help determine what is required to achieve customer and shareholder alignment (Kim, 2006; Soosay et al., 2008; Srivastava et al., 1999).

\subsection{Information sharing (IS)}

The SLR identifies information-sharing as a crucial enabler for supply chain alignment (Frohlich and Westbrook, 2001; Tarn et al., 2002; Soosay et al., 2008). The lack of transparency and visibility across supply chains is the main obstacle to internal and external alignment (Christopher and Gattorna, 2005) and collaborative planning (Barratt, 2003; Holweg, 2005). The lack of alignment between Information Technology (IT) and Information Systems (IS) with business strategy has long been recognised as a major inhibitor to organisational success (Luftman, 1998). Incompatible information systems, standards and operating procedures often inhibit collaboration across independent enterprises (Houlihan, 1985). Information sharing helps to improve visibility (Lethonen et al., 2005) and therefore improves the allocation of inventory (Lee et al., 1997), production scheduling and knowledge transfer process (Bagchi and Skjoett-Larsen, 2003; Barratt and Oliveira, 2001; Simatupang and Sridharan, 2004).

It is not enough to simply share information - it is crucial to share quality information. Quality of information is achieved by sharing relevant (IS1), accurate (IS2) and sufficient information (IS3) in a timely manner (IS4). For example, the sharing of information on operations cost will help in making effective cost trade-off decisions (Bowersox and Daugherty, 1995; Frohlich and Westbrook, 2001) and the sharing of order creation information will reduce the bullwhip effect (Lee et al., 1997). Relevant information facilitates demand management (Lummus and Vokurka, 1999) whereas relevant but delayed information can result in amplified demand (Lee et al., 1997). Thus, the importance of sufficient, accurate and timely information has been mentioned in several studies (Bourland et al., 1996; Lee and Whang, 1998; Huang et al., 2003; Li and Lin, 2006; Lehtonen et al., 2005; Kannan and Tan, 2010). Early capture of demand information (Campbel and Sankaranl, 2005; Buyukozkan, 2004) and early notification of change (Osterlund and Loven, 2005) will often improve customer responsiveness and reduce cost. Further, in today's information-rich supply chains, it is essential for a focal firm to acquire just enough information and not be overloaded by too much information. One of the least studied areas of information system research is the information processing capability. Without this, it is hard to capture the value of shared information (IS5). Thus, it is essential to understand the value of information and how shared information (Sahin and Robinson, 2002) may be processed to improve supply chain performance.

\subsection{Business performance management system (PM)}

The SLR indicated that a performance measurement system (PM) would either enable or inhibit alignment. Melnyk et al. (2004) suggested that performance measurement system is ultimately 
responsible for maintaining alignment and coordination. PM can enable alignment by motivating staff and ensuring alignment in strategy and process (Waggoner et al., 1999; Gunasekaran et al., 2001; Holmberg, 2000; Chan et al., 2003; Morgan, 2004). Also, PM helps decision-making by indicating how well an organisation/ supply chain has performed, where they currently are and where they need to be. To do this effectively PM would need to be relevant and linked with strategic objectives (PM1) and the measures have to be agreed and shared by the users (PM2) especially when they involve different groups and organisation units (Fawcett and Cooper, 2001; Chenhall, 2005). Often the current approaches to PM encourage functional sub-optimisation by driving the wrong organisational behaviours in supply chains (Storey et al., 2005; Morash et al., 1996). PM can be inhibiting when it lacks relevance to organisational goals and strategic objectives (Schmenner and Vollmann, 1994) or lacks useful metrics which can be changed as necessary to match changing strategic intent (Neely, 2002; O'Mara et al., 1998; Toni and Tonchia, 1996; Maskell, 1991). For performance, an individual has no direct control; PM has to be designed to act as a communication mechanism which encourages teamwork, establishes accountability and priorities Robson (2004). This would make PM a reflection of strategic goals, representation of complex relationships amongst partners, and a concern for both internal and external stakeholders (Chan et al., 2003; Gunasekaran et al., 2001; Maku et al., 2005). A lack of training and understanding of this potentially complex link can lead to decisions that are made based on measurement that are not aligned with strategy.

Essentially, the performance target is a statement of strategic intent and strategic intent is a target setting exercise. Inappropriate target setting (PM3) may lead to narrow focus, sub-optimisation and conflicting goals (Neely, 2002). This means that employees are provided with incentives to improve certain measures without taking a broader scope, hence not creating holistic 'improvements' and ultimately leading to tensions between functions (Muratoglu, 2008). This view is supported by Storey et al. (2005) who found that SMART (Specific, Measurable, Achievable, Realistic and Timely) targets and the desire for individual accountability have contributed to functional sub-optimisation. They proposed that an effective performance measurement needs to balance the requirements of the individual with the requirements of the organisation and wider supply chain. Yasin et al. (2005) proposed the use of a cross-departmental reward system as a means of overcoming this. Overall the effect desired of an aligning PM would be one that provoked the timely provision of feedback (PM4) which would, in turn, facilitate decision-making for continual improvement (Wilcox and Bourne, 2003; Franco-Santos et al., 2004) thus allowing the appropriate course of action to be taken.

\section{Theoretical hypotheses for supply chain alignment}

The six constructs for enablers developed (Table 5) are essential for achieving both shareholder and customer alignment. Taking these results as a starting point this section establishes a set of hypotheses for the relationships between the six enablers and alignment (shareholder and customer) and value (shareholder and customer).

\subsection{Relationships between enablers and shareholder and customer alignment}

Before establishing the impacts of supply chain alignment there is a need to clarify the concepts of shareholder and customer alignment. Shareholder alignment is achieved when business strategy, supply chain strategy and employees' expectations are aligned with shareholder objectives, and the business strategy is well defined to ensure organisational change to meet shareholder objectives. Customer alignment is the state where business strategy and supply chain strategy are aligned to meet customer expectations, and the business and supply chain strategies are designed to adjust the supply 
chain to meet customer needs. Table 6 and summarise some hypotheses of the impacts of supply chain alignment enablers on shareholder alignment (H1a-H6a) and customer alignment (H1b-H6b), which are theoretically developed based on the SLR. These hypotheses are motivated as follows.

Table 6. Hypotheses relating enablers to alignment

\begin{tabular}{|l|l|l|}
\hline $\begin{array}{l}\text { Phenomena } \\
\text { Influenced }\end{array}$ & \multicolumn{2}{|l|}{ Hypotheses } \\
\hline $\begin{array}{l}\text { Shareholder } \\
\text { alignment } \\
\text { (SA) }\end{array}$ & H1a & Organisation structure (OS) positively affects shareholder alignment (SA) \\
\cline { 2 - 3 } & H2a & Internal relational behaviour (IR) positively affects shareholder alignment (SA) \\
\cline { 2 - 4 } & H3a & Customer relational behaviour (CR) positively affects shareholder alignment (SA) \\
\cline { 2 - 4 } & H4a & Top management support (TS) positively affects shareholder alignment (SA) \\
\cline { 2 - 3 } & H5a & $\begin{array}{l}\text { Business performance measurement system (PM) positively affects } \\
\text { alignment (SA) }\end{array}$ \\
\cline { 2 - 4 } & H6a & Information sharing (IS) positively affects shareholder alignment (SA) \\
\hline \multirow{4}{*}{$\begin{array}{l}\text { Custignment } \\
\text { (CA) }\end{array}$} & H1b & Organisation structure (OS) positively affects customer alignment (CA) \\
\cline { 2 - 3 } & H2b & Internal relational behaviour (IR) positively affects customer alignment (CA) \\
\cline { 2 - 3 } & H3b & Customer relational behaviour (CR) positively affects customer alignment (CA) \\
\cline { 2 - 3 } & H4b & Top management support (TS) positively affects customer alignment (CA) \\
\cline { 2 - 3 } & H5b & $\begin{array}{l}\text { Business performance measurement system (PM) positively affects customer alignment } \\
\text { (CA) }\end{array}$ \\
\cline { 2 - 3 } & H6b & Information sharing (IS) positively affects customer alignment (CA) \\
\hline
\end{tabular}

In order to achieve shareholder alignment there is a need to make organisational structures compatible with business strategy and shareholder expectations (Thompson, 1976; Lawrence and Lorsch, 1976). The SLR affirms a more process-oriented organisational structure with the ability to enable/support cross-functional knowledge exchange and inter-departmental activities to achieve cost effectiveness (Davenport, 1993; Lewis and Slack, 2003; Ettlie and Stoll, 1990). A process-oriented organisational structure which facilitates inter-functional collaboration is also necessary for meeting customer needs. Organisations with functional silos are often blamed for the inability to respond to various customer demands (Beth et al., 2003, Pagell, 2004; van Hoek and Mitchell, 2006). However, when an organisation is segmented and aligned to processes which focus on different value streams, then it is more likely to meet customer needs with the same resources (Godsell et al., 2006). Furthermore, appropriate process owners with a wider control span are able to stimulate complex strategic integration (Burgelman and Doz, 2001). These arguments suggest the above-mentioned characteristics of organisational structure are effective in meeting shareholder alignment, especially in terms of capital efficiency and customer alignment, and delivery service, leading to the formulation of hypotheses H1a and H1b.

In addition, internal relational behaviour encompassing the ability to achieve mutual understanding and support joint planning among functions, is essential for improving cost effectiveness (O'LearyKelly and Flores, 2002; Pagell, 2004; Anderson and Narus, 1990). Internal relational behaviour is also essential for meeting customer needs. Customer delivery performance can be improved when suppliers cooperate with customers to re-align order penetration points (Auramo et al., 2004). It is argued that internal integration is the central link between customers and an organisation's responses to changes in the market (Flynn et al., 2010). The improvement of cross-functional relationships and the use of cross-functional teams often promote mutual understanding towards a more customer responsive culture (Godsell et al., 2006) and mutually accepted objectives (Pagell, 2004). Without a close internal relationship, it is very difficult for top management to implement any strategy. Therefore, we argue that internal relational behaviour is an enabler for customer alignment as well as shareholder alignment. These arguments suggest internal relational behaviour is required to achieve 
shareholder alignment and customer alignment, leading to the formulation of hypotheses $\mathrm{H} 2 \mathrm{a}$ and $\mathrm{H} 2 \mathrm{~b}$.

The next enabler - customer relational behaviour - facilitates goal/cost/profit sharing, and joint planning and problem-solving with customers to ensure customer loyalty and eventually revenue growth, and subsequently creates shareholder alignment (Day, 1994; Auramo et al., 2004; Tracey et al., 2005). Customer relational behaviour is crucial for the alignment of customer demand with production planning and replenishment (Lee and Whang, 1998; Barratt and Oliviera, 2001) to lower inventory (working capital) cost and at the same time maintain delivery performance. Thus, customer relational behaviour is perhaps one of the most significant enablers for customer alignment. However, it is also crucial for achieving shareholder alignment because one way firms align their customers' interests with their own is by redefining the terms of their relationships so that firms share risk, costs, and rewards equitably (Lee, 2004). Such an alignment is required to ensure that everyone in the chain has the same objective, i.e. to deliver the best service to the end consumers (Lee, 2004). This means that customer relational behaviour may be able to influence the customers such that shareholders' interests are safeguarded. These arguments suggest internal relational behaviour is required to achieve shareholder alignment and customer alignment, leading to the formulation of hypotheses $\mathrm{H} 3 \mathrm{a}$ and H3b.

Top management is the crucial channel between shareholders and employees because they translate shareholders' goals into business strategies and support employees to achieve business strategies (Tamas, 2000). Top management who listens to employees invests in human assets through the provision of training leading to a better shareholder alignment (Buhner, 1997). Also, top management's participation in operational issues and encouragement of open communication helps to align employees' behaviour (Gerbing et al., 1994). Brown et al. (2007) argue that involving manufacturing/operations managers in the strategic planning process helps align manufacturing and business strategy, and this alignment is associated with higher manufacturing performance. Furthermore, top management support in supply chain management is crucial in aligning employees' behaviour in contributing to cost saving and customer service improvement, leading to customer alignment. Top management not only have the authority to provide resources, but also to direct the supply chain and business unit strategies towards meeting customer needs. These arguments suggest top management support is required to achieve shareholder alignment and customer alignment, leading to the formulation of hypotheses $\mathrm{H} 4 \mathrm{a}$ and $\mathrm{H} 4 \mathrm{~b}$.

Information sharing is argued to have a significant impact on shareholder and customer alignment. Increased intensity of organisational connectivity due to information sharing often decreases production cost (Clark et al., 2001) and increases customer service because accurate information (Bourland et al., 1996; Lee and Whang, 1998) combined with the capability to use shared information (Sahin and Robinson, 2002) is required to plan production and inventory effectively. During the strategy formulation and implementation information sharing across the hierarchy, it is essential to achieve buy in and therefore alignment between business strategy and employees. These arguments suggest information sharing is required to achieve shareholder alignment and customer alignment, leading to the formulation of hypotheses H5a and H5b.

People act according to incentives which are often related to performance targets. Thus, business performance management systems, if properly aligned with shareholders' objectives, will act as catalysts for change and allow employees to contribute to shareholders' objectives (Schmenner and Vollmann, 1994; Gunasekaran et al., 2001; Morgan, 2004), leading to the formulation of hypothesis 
H6a. Furthermore, employees act according to rewards and performance targets and if these are not aligned to business strategies and customer needs, then there will be a greater tendency to suboptimise, which may adversely affect customer delivery performance. Finally, when employees act upon accurate and timely customer demand information, they will be able to respond to customer needs more accurately and quicker. Furthermore, by using shared information systems it is possible to achieve full potential in developing flexible pricing strategies and tailored offerings for individual customers (Clemons and Weber, 1994). Thus, we take the view that supply chain alignment is required to deliver value to the customer (Christopher, 1998) in an efficient manner that will also deliver shareholder value (Christopher and Ryals, 1999), leading to the formulation of hypothesis $\mathrm{H7}$ and $\mathrm{H} 8$.

Even though the above discussion supports positive relationships between supply chain alignment enablers and shareholder and customer alignment, it is recognised that supply chain alignment efforts cost money and they may disturb the customer service process. Firms which are not skilful in implementing supply chain alignment may find themselves encumbered with high costs and low customer service and therefore be unable to achieve shareholder and customer alignment. Thus, for some firms, we might find insignificant or even negative correlations between supply chain alignment enablers, and shareholder and customer alignment.

\subsection{Relationships between shareholder and customer alignment and value}

Based on the literature, hypotheses about the complex relationships between shareholder and customer alignment and value are developed. The relationship between shareholder alignment and shareholder value is straight-forward. When the business unit and supply chain strategies and employees are aligned to meet shareholders' objectives, such as working capital efficiency and revenue growth, then it is more likely for an organisation to provide higher earnings per share, leading to hypothesis H7. Similarly, for customer alignment and customer value, when the business unit and supply chain strategies are aligned to meet customer needs, it is then more likely to meet customer needs, supporting hypothesis H8.

Table 6: Hypotheses relating shareholder and customer alignment to each other and customer and shareholder value.

\begin{tabular}{|l|l|l|}
\hline $\begin{array}{l}\text { Phenomena } \\
\text { Influenced }\end{array}$ & \multicolumn{2}{|l|}{ Hypotheses } \\
\hline $\begin{array}{l}\text { Impacts of } \\
\text { shareholder } \\
\text { alignment }\end{array}$ & $\mathrm{H} 7$ & Shareholder alignment positively influences shareholder value \\
\cline { 2 - 3 } $\begin{array}{l}\text { Impacts of } \\
\text { customer } \\
\text { alignment }\end{array}$ & $\mathrm{H} 8$ & Shareholder alignment positively influences customer alignment \\
\cline { 2 - 3 } & $\mathrm{H} 9 \mathrm{~b}$ & Customer alignment positively influences customer value \\
\hline $\begin{array}{l}\text { Joint impacts of } \\
\text { shareholder and } \\
\text { customer } \\
\text { alignment }\end{array}$ & $\mathrm{H} 12$ & $\begin{array}{l}\text { Companies with both high customer alignment and high shareholder alignment have } \\
\text { higher customer and shareholder value than companies with lower customer } \\
\text { alignment and shareholder alignment. }\end{array}$ \\
\hline
\end{tabular}

Challenge comes when shareholder alignment/value and customer alignment/value are considered simultaneously. The SLR reveals that shareholder value has hardly been considered together with customer value in the past. For example, the value chain theory of Porter (1985) focuses on the building blocks by which a firm creates a product valuable to its buyers, taking shareholder value for granted. Day and Fahey (1990) mentioned the importance of alignment between business unit strategies and shareholder value. Only since the mid-1990s has some literature started to consider both 
shareholder and customer value (Bourguignon, 2005). Still, there is debate in the literature over which of these values should take priority. Some argue that organisations are in business primarily to maximise shareholder value (Cornelius and Davies, 1997; Rappaport, 1987) and can do so by also delivering customer value and therefore maintaining competitiveness. Frohlich (2002) argued that the lack of alignment between business models and practices and customer needs will have an adverse effect on shareholder alignment. Under this perspective, shareholder alignment and customer alignment appear to reinforce each other, meaning that shareholder alignment positively affects customer alignment and vice versa, leading to hypotheses H9a and H9b.

Others have argued that customer alignment comes first because a business is more likely to achieve its goals when it organises itself to meet the current and potential needs of customers more effectively than its competitors (Doyle, 1994; Drucker, 2001; Copulsky, 1991; Laitamaki and Kordupleski, 1997). An alternative to this trade-off perspective is that organisations need to be able to balance between the two (Feurer and Chaharbaghi, 1994; Cleland and Bruno, 1997) as they can be conflicting and can destroy each other.

In a way customer value ensures customer loyalty and thus promises continuous revenue and contributing to shareholder value, and shareholder value promises continuous investment which supports the implementation of the business unit and supply chain strategies to meet customer need (Slater and Narver, 1994; Kaplan and Norton, 2004). Thus, we argue that both shareholder alignment and customer alignment are reinforcing each other (hypotheses H10 and H11) and both alignments are required to contribute to both customer and shareholder value (hypothesis H12). Marquez and Blanchar (2006) emphasise the importance of connecting customer value with business targets, thus suggesting the joint effects of customer alignment and shareholder alignment on shareholder and customer value (hypothesis H12).

\subsection{Relationships between supply chain alignment enablers}

As indicated by the previous section on supply chain alignment enablers (section 4), potentially causal relationships could exist between the enablers. The relationships among these enablers are tenuous and complex and not well supported in the literature, either theoretically or empirically. Nonetheless it would be valuable to understand such relationships. The literature review suggests that organisational structure and top management support are two enablers which significantly reinforce other enablers. A process-oriented organisation with a greater span of control given to a supply chain manager as well as appropriate top management support is likely to improve internal relational behaviour, customer relational behaviour and information sharing within the supply chain. This will be further enhanced by performance measurement systems with share metrics, targets and incentives designed to encourage these behaviours. Furthermore, top management support is required to change the organisational structure and performance measurement system so that internal relational behaviour, external relational behaviour and information sharing are aligned with the shareholder and customer value. In terms of analysis, that means it is likely to find positive relationships among all these enablers, and is more likely to find top management support, performance management system and organisation structure as the main predictors of internal relational behaviour, customer relational behaviour and information sharing.

Indeed a more complex relationship among these enablers has been reviewed. For example, it is found that information sharing enables functional integration and co-alignment among organisation structure, information technology and organisation planning (Pollalis, 2003). This study, though valuable, is inadequate for forming the foundation of a more concrete theoretical model. However, 
such an important understanding, if achieved, will certainly provide a significant contribution to theory and practice.

\section{Conclusion}

Based on a systematic literature review, this paper identifies, and develops the constructs for, six enablers of supply chain alignment: organisational structure, internal relational behaviour, customer relational behaviour, top management support, information sharing and business performance measurement system. A set of hypotheses are developed, which posit the positive impacts of the six enablers on shareholder and customer alignment, and the complex relationships between shareholder alignment/value and customer alignment/value. The paper culminates in a series of hypotheses, which are grounded in the literature and together form the basis for developing a theoretical model. This is succeeded by a systematic approach in reviewing publications from journals across operations and technology, general management, marketing, information management, organisation management, accounting and strategy. The main contribution of this literature review is that it brings together the theoretical arguments and findings from a disparate and multi-disciplinary body of literature (where 72 papers span 43 journals) and synthesises them into a set of enablers and hypotheses of supply chain alignment, which takes into account both shareholder and customer value.

While the proposed hypotheses remain theoretical, it is now possible to test them on a population of companies (residing within supply chains) and understand the relative significance of the various enablers to alignment; this can also be related to contextual factors such as sector, position in supply chain and company size. Further, the significance of shareholder and customer alignment on the delivery of shareholder and customer value can be examined leading to the development of a theory of supply chain alignment. In practice, companies are struggling with supply chain alignment. Increasingly, they are required to align their business functions, and supply chains are required to align their constituent companies, to become more customer oriented and deliver increased levels of customer value. The identified enablers and proposed hypotheses have the potential to provide practical guidance on how to improve both shareholder and customer alignment. They could be used to assess the current state of existing enablers in the company, and wider supply chain, in order to identify practices that need improvement. They could be further used by practitioners to benchmark supply chain alignment practices in a particular supply chain.

As with any study there are limitations to this paper. Customer and shareholder alignment is emphasised, because a supply chain should always aim to be aligned with final customers' needs and shareholders objectives, as discussed in the introduction. Alignment with suppliers is not considered to the same extent, although every member of a supply chain, practises customer relational behaviour, therefore supplier relations are included indirectly. Further, information sharing covers sharing of information with internal functions, customers and suppliers. On a separate point, the hypotheses suggest causal relationships between the enablers, alignment (shareholder and customer) and value (shareholder and customer). However, these relationships were rarely made explicit in the literature and there is a lack of empirical evidence. Moreover, we focus on the role of enablers in customer and shareholder alignment but there may be many other inhibitors. Inhibitors can be real or imaginary, utility or psychic, and not all managers are conscious of their own perceptions of the inhibitors or enablers (Groth, 1994). Finally, the interactions between the enablers are only briefly discussed, and could be an area for further research. Thus, the further testing of the hypotheses established in this paper should take this into account during data collection. 


\section{References}

Akkermans, H. Bogerd, P. and Vos, B. (1999), "Virtuous and vicious cycles on the road towards international supply chain management", International Journal of Operations and Production Management, vol. 19, iss. 5/6, p. 565 .

Aldrich, H. and Herker, D. (1977), "Boundary spanning roles and organization structure", The Academy of Management Review, 2(2), pp. 217-230.

Anderson, J.C. and Narus, J.A., (1990), "A model of distribution firm and manufacturer firm working partnerships", Journal of Marketing, vol. 54, no. 1, pp. 42-58.

Auramo, J., Tanskanen, K and Smaros, J. (2004), "Increasing Operational Efficiency Through Improved Customer Service: Process Maintenance Case", International Journal of Logistics: Research and Applications, vol. 7, no. 3, 167-180.

Bagchi, P. K. and Skjoett-Larsen, T. (2003), "Integration of information technology and organizations in a supply chain", International Journal of Logistics Management, vol. 14, no. 1, p. 89.

Baier, C., Hartman, E. and Moser, R. (2008), "Strategic alignment and purchasing efficacy: an exploratory analysis of their impact on financial performance", Journal of Supply Chain Management, vol. 44, no. 4, pp. 36-52.

Barratt, M. (2003), "Positioning the Role of Collaborative Planning in Grocery Supply Chains", International Journal of Logistics Management, vol. 14, no. 2, p. 53.

Barratt, M. and Oliveira, A. (2001), "Exploring the experiences of collaborative planning initiatives", International Journal of Physical Distribution \& Logistics Management, vol. 31, no. 4, p. 266.

Bessant, J., Caffyn, S., Gibert, J., Harding, R. and Webb, S. (1994), "Rediscovering continuous improvement", Technovation, vol. 14, iss. 1, p. 17.

Beth, S., Burt, D.N., Capacino, W., Gopal, C., Lee, H.L., Lynch, R.P., Morris, S., (2003), "Supply chain challenges: building relationships", Harvard Business Review, vol. 81, no. 7, pp. 64-73.

Brown, C.V. and Magill, S.L. (1994), "Alignment of the IS functions with the enterprise: toward a model of antecedents", MIS Quarterly, vol. 18, no. 4, pp. 371-403.

Brown, S., Squire, B. and Blackmon, K. (2007), "The contribution of manufacturing strategy involvement and alignment to world class manufacturing performance", International Journal of Operations Management and Production Management, vol. 27, no. 3, pp. 282-302.

Bourguignon, A. (2005), "Management accounting and value creation: The profit and loss of reification", Critical Perspectives on Accounting, vol. 16, no. 4, p. 353.

Bourland, K.E., Powell, S.G., Pyke, D.F. (1996), Exploiting timely demand information to reduce inventories, European Journal of Operational Research, vol. 92, no. 2, 239-253.

Bowersox, D.J. and Daugherty, P.J. (1995), "Logistics paradigms: the impact of information technology", Journal of Business Logistics, vol. 16, no. 1, pp. 65-80.

Buhner, R. (1997), "Increasing shareholder value through human asset management", Long Range Planning, vol. 30, no. 5, p. 710.

Burgelman, R.A. and Doz, Y.L. (2001), “The power of strategic integration”, MIT Sloan Management Review, vol. 42, no. 3, pp. 28-38. 
Buyukozkan, G. (2004), "An organizational information network for corporate responsiveness and enhanced performance", Journal of Manufacturing Technology Management, vol. 15, no. 1, p. 57.

Cachon, G.P. and Lariviere, M.A. (2005), "Supply chain coordination with revenue-sharing contracts, Strengths and Limitations", Management Science, 51(1), pp. 30-44.

Carrillat, F., Jaramillo, F. and Locander, W. (2004), "Market-driving organisations: a framework", Academy of Marketing Science Review, no. 5, pp. 1-14.

Campbel, J. and Sankaranl, J. (2005), "An inductive framework for enhancing supply chain integration", International Journal of Production Research, vol. 43, no. 16, p. 3321.

Campbell, A.J. (1998), "Cooperation in international value chains: comparing an exporter's supplier versus customer relationships", The Journal of Business \& Industrial Marketing, vol. 13, no. 1, p. 22.

Chenhall, R.H. (2005), "Integrative strategic performance measurement systems, strategic alignment", Accounting, Organizations and Society, vol. 30, no. 5, p. 395.

Childerhouse, P., Aitken, J. and Towill, D.R. (2002), "Analysis and design of focused demand chains", Journal of Operations Management, vol. 20, no. 6, p. 675.

Christopher, M. (1998), Logistics and supply chain management: strategies for reducing cost and improving service, $\left(2^{\text {nd }}\right.$ edition$)$, Pearson, Essex UK.

Christopher, M. and Gattorna, J. (2005), "Supply chain cost management and value-based pricing", Industrial Marketing Management, vol. 34, no. 2, p. 115.

Christopher, M. and Ryals, L. (1999), "Supply chain strategy: its impact on shareholder value", International Journal of Logistics Management, Vol. 10, no. 1, pp. 1-10.

Christopher, M., Lowson, R. and Peck, H. (2004), "Creating agile supply chains in the fashion industry”, International Journal of Retail and Distribution Management, vol. 31, no. 4, p. 235.

Copulsky, W. (1991), "Balancing the needs of customers and shareholders", Journal of Business Strategy, vol. 12, no. 6, pp. 44-45.

Cornelius, I. and Davies, M. (1997) Shareholder Value, FT Financial Publishing, London.

Chan, F.T.S., Qi, H.J., Chan, H.K., Lau, H.C.W. and Ip, R.W.L. (2003), "A conceptual model of performance measurement for supply chains", Management Decision, vol. 41, no. 7, p. 635.

Chung, W.W.C. and Leung, S.W.F. (2005), "Collaborative planning, forecasting and replenishment: a case study in copper clad laminate industry", Production Planning \& Control, vol. 16, no. 6, p. 563.

Clark, T.H., Croson, D.C. and Schiano, W.T. (2001), "A Hierarchical Model of Supply-Chain Integration: Information Sharing and Operational Interdependence in the US Grocery Channel", Information Technology and Management, vol. 2, no. 3, p. 261.

Cleland, A.S. and Bruno, A.V. (1997), "Building customer and shareholder value", Strategy \& Leadership, Vol. 25, no. 3, pp. 22-28

Clemons, E.K. and Weber, B.W. (1994), "Segmentation, differentiation, and flexible pricing: Experiences with information technology and segment-tailored strategies", Journal of Management Information Systems, vol. 11, no. 2, p. 9. 
Danese, P. and Romano, P. (2004), Improving inter-functional coordination to face high product variety and frequent modifications, International Journal of Operations Management, vol. 24, no. $9 / 10$, pp. $863-885$.

Davenport, T.H. (1993), Process innovation: reengineering work through information technology, Harvard Business School Press.

Day, G.S. (1994), "The capabilities of market-driven organizations", Journal of Marketing, vol. 58, no. 4, pp. 37-52.

Day, G.S. and Fahey, L. (1990), "Putting Strategy into Shareholder Value Analysis", Harvard Business Review, vol. 68, no. 2, p. 156.

Denyer, D. and Tranfield, T. (2009), Producing a systematic review, in Buchanan, D.A. and Bryman, A. (Eds.), The SAGE handbook of organizational research methods, SAGE, London

Doyle, P. (1994), Marketing management and strategy, Prentice Hall International (UK) Ltd, Hemel Hempstead.

Drucker, P.F. (2001), "What is our business?” Executive Excellence, vol. 18, no. 6, p. 3.

Earl, M. (2002), "The new and the old of business process redesign", The Journal of Strategic Information Systems, 3(1), pp. 5-22.

Ellinger, E. (2000), "Improving marketing/logistics cross-functional collaborations in the supply chain", Industrial Marketing Management, vol. 29, no. 1, p85.

Eng, T-Y. (2006), "An investigation into the mediating role of cross-functional coordination on the linkage between organizational norms and SCM performance", Industrial Marketing Management, 35(6), pp. 762-773.

Esper, T.L., Ellinger, A.E., Stank, T.P., Flint, D.J. and Moon, M. (2010), "Demand and supply integration: a conceptual framework of value creation through knowledge management", Academy of Marketing Science Journal, vol. 38, iss. 1, p.5.

Ettlie, J.E., and Reza E. (1992), "Organizational integration and process innovation" Academy of Management Journal, vol. 34, pp. 795 - 827

Fassoula, E.D. (2006), "Transforming the supply chain”, Journal of Manufacturing Technology Management, vol. 17, iss. 6, pp. 848-860.

Fawcett, S.E. and Cooper, M.B. (2001), "Process integration for competitive success: Benchmarking barriers and bridges", Benchmarking, vol. 8, no. 5, p. 396.

Fawcett, S.E. and Magnan, G.M. (2002), "The rhetoric and reality of supply chain integration", International Journal of Physical Distribution \& Logistics Management, 32(5), pp. 339-361.

Fawcett, S.E., Odgen, J.A., Magnan, G.M. and Cooper, M.B. (2006), Organizational commitment and governance for supply chain success, International Journal of Physical Distribution \& Logistics Management, vol. 36, no., 1, pp. 22-35.

Feurer, R. and Chaharbaghi, K. (1994), "Defining competitiveness: A holistic approach", Management Decision, vol. 32, no. 2, p. 49.

Flynn, B.B., Huo, B., and Zhao, X., (2010), "The impact of supply chain integration on performance: a contingency and configuration approach", Journal of Operations Management, vol. 28, pp. 5871. 
Franco-Santos, M., Marr, B., Martinez, V., Gray, D., Adams, C., Micheli, P., Bourne, M., Kennerley, M., Mason, S. and Neely A. Towards a Definition of a Business Performance Measurement System. PMA 2004 Conference "Performance Measurement and Management Public and Private" Edinburgh International Conference Centre, 27-30, July 2004.

Frohlich, M.T. (2002), "e-integration in the supply chain: Barriers and performance", Decision Sciences, vol. 33, no. 4, p. 537.

Frohlich, M.T. and Westbrook, R. (2002), "Arcs of integration: an international study of supply chain strategies", Journal of Operations Management, vol. 19, no. (2), 185-200.

Gattorna, J. L., Chorn, N. H. and Day, A. (1991), "Pathways to Customers: Reducing Complexity in the Logistics Pipeline", International Journal of Physical Distribution \& Logistics Management, vol. 21 , no. 8 , p. 5 .

Gattorna, J. L. and Walters, D. W. (1996), Managing the Supply Chain: A Strategic Perspective, Palgrave.

Gattorna, J. L. (1998), Strategic Supply Chain Alignment, Gower, Surrey.

Gattorna, J. L. (2009), Dynamic Supply Chain Alignment, Gower, Surrey.George, M., Freeling, A. and Court, D. (1994), "Reinventing the marketing organization", The McKinsey Quarterly,no. 4, p. 43.

Gerbing, D.W., Hamilton, J.G. and Freeman, E.B. (1994), "A large-scale second-order structural equation model of the influence of management participation on organizational planning benefits", Journal of Management, vol. 20, no. 4, pp. 859-85.

Godsell, J., Harrison, A., Emberson, C. and Storey, J. (2006), "Customer Responsive Supply Chain Strategy: An Unnatural Act?", International Journal of Logistics: Research and Applications, vol. 9, no. 1, pp. 47-56.

Godsell J., Juttner, J. and Christopher, M. (2005), Demand chain management: The missing link, in 10th International Symposium on Logistics, Lisbon.

Groth, J.C. (1994), "Managing action inhibitors to increase sales", Marketing Intelligence \& Planning, vol. 12, no. 4, p. 4.

Gunasekaran, A., Patel, C. and Tirtiroglu, E. (2001), 'Performance measures and metrics in a supply chain environment', International Journal of Operations \& Production Management, vol. 21, no.1/2, pp. 71-87.

Halldórsson, A., Larson, P. D. and Poist, R. F. (2008), "Supply chain management: a comparison of Scandinavian and American perspectives", International Journal of Physical Distribution \& Logistics Management, vol. 38, iss. 2, pp. 126-142.

Hamel, G. and Prahalad, C. (1989), "Strategic intent: to revitalise corporate performance we need a whole new model of strategy", Harvard Business Review, vol. 67, iss. 3, p.63.

Hammer, M. and Champy, J. (1993), Reengineering the corporation: a manifesto for business revolution, Collins Business Essentials.

Harrison, A. (1998), "Investigating business processes: does process simplification always work?" Business Process Management Journal, vol. 4, no. 2, 1998, pp. 137-153.

Hartley, J.L. (2000), "Collaborative value analysis: Experiences from the automotive industry", Journal of Supply Chain Management, vol. 36, no. 4, p. 27. 
Heskett, J.L., Jones, T.O., Loveman, G.W., Sasser, W.E., Jr and Schlesinger, L.A. (1994), "Putting the service-profit chain to work", Harvard Business Review, vol. 72, no. 2, p. 164.

Hill, C.A. and Scudder, G.D. (2002), "The use of electronic data interchange for supply chain coordination in the food industry", Journal of Operations Management, vol. 20, no. 4, p. 375.

Hoffman, N.P. (2000), "An Examination of the 'Sustainable Competitive Advantage' Concept: Past, Present, and Future”, Academy of Marketing Science Review, vol. 2000, p. 1.

Holmberg, S. (2000), “A systems perspective on supply chain measurements", International Journal of Physical Distribution \& Logistics Management, vol. 30, no. 10, pp. 847-868.

Holweg, M. (2005), "An investigation into supplier responsiveness: Empirical evidence from the automotive industry", International Journal of Logistics Management, vol. 16, no. 1, p. 96.

Houlihan, J.B. (1985) "International Supply Chain Management, International Journal of Physical Distribution and Materials Management, vol. 15, no. 1 pp. 22-38.

Huang, G. Q., Lau, J. S. K., and Mak, K. L. (2003), The impacts of sharing production information on supply chain dynamics: A review of the literature, International Journal of Production Research, 41(7), pp. 1483-1517.

Jaworski, B. J. and Kohli, A.K. (1993), Market orientation: antecedents and consequences, Journal of Marketing, vol. 57, no. 3, 53-70.

Jeong, J.S., and Hong, P. (2007), "Customer orientation and performance outcomes in supply chain management”, Journal of Enterprise Information Management, 20(5), pp. 578-594.

Johnson, G. and Scholes, K. (1999), Exploring corporate strategy: text and cases, $5^{\text {th }}$ edition, Prentice Hall, Hemel Hempstead.

Jones, T.C. and Riley, D.W. (1985), "Using Inventory for Competitive Advantage Through Supply Chain Management", International Journal of Physical Distribution \& Materials Management, vol. 15 , no. 5 , p. 16.

Kahn, K.B. and Mentzer, J.T. (1996), Logistics and interdepartment integration, International Journal of Physical Distribution \& Logistics Management, vol., 26, no. 9, pp. 6-14.

Kalchschmidt, M., Zotteri, G. and Verganti, R. (2003), "Inventory management in a multi-echelon spare parts supply chain", International Journal of Production Economics, vol. 81/82, p. 397.

Kannan, V.R. and Tan, K.C. (2010), "Supply chain integration: cluster analysis of the impact of span of integration", Supply Chain Management: an International Journal, vol. 15, iss. 3, pp. 207215.

Kaplan, R.S. and Norton, D.P. (2004), "The strategy map: guide to aligning intangible assets", Strategy \& Leadership, vol. 32, no. 5, p. 10.

Karapetrovic, S. and Willborn, W. (2002), "Self-audit of process performance", The International Journal of Quality \& Reliability Management, 19(1), pp. 24-45.

Kathuria, R., Joshi, M.P. and Porth, S.J. (2007), "Organizational alignment and performance: past, present and future", Management Decision, vol. 45, no. 3, pp. 503-517.

Kauremaa, J., Kärkkäinen, M. and Ala-Risku, T. (2009), "Customer initiated interorganizational information systems: The operational impacts and obstacles for small and medium sized suppliers”, International Journal of Production Economics, vol. 119, iss. 2, p. 228. 
Kelley, H.H. and Thibaut, J.W. (1954), Experimental studies of group problem solving and process, in G. Lindzey (ed.), Handbook of Social Psychology, vol. 2, Addison-Wesley, Cambridge MA.

Kim, S.W. (2006), "The effect of supply chain integration on the alignment between corporate competitive capability and supply chain operational capability", International Journal of Operations Management, 26(10), pp. 1084-1107.

Laitamaki, J. and Kordupleski, R. (1997), "Building and deploying profitable growth strategies based on the waterfall of customer value added", European Management Journal, vol. 15, no. 2, p. 158.

Lambert, D.M., Cooper, M.C. and Pagh, J.D. (1998), "Supply chain management: Implementation issues and research opportunities", International Journal of Logistics Management, vol. 9, no. 2, p. 1.

Lambert, D.M., García-Dastugue, S.J. and Croxton, K.L. (2005), "An Evaluation of Process-Oriented Supply Chain Management Frameworks", Journal of Business Logistics, vol. 26, no. 1, p. 25.

Lawrence, P. and Lorsch, J. (1967), Organization and environment: managing differentiation and integration, Irwin, Illinois.

Lee, H. (2004), “The Triple-A supply chain”, Harvard Business Review, Vol. 82, no. 10, pp. 102-112.

Lee, H. and Whang, S. (2000), "Information sharing in supply chain", International Journal of Technology Management, vol. 20, no. 3/4, 373-387.

Lee, H.L., Padmanabham, V., and Whang, S. (1997), "The bullwhip effect in supply chains", Sloan Management Review, vol. 38, no. 3, pp. 93-102.

Lehtonen, J., Småros, J. and Holmström, J. (2005), "The effect of demand visibility in product introductions", International Journal of Physical Distribution \& Logistics Management, vol. 35, no. 2 , p. 101.

Lewis, M. and Slack, N. (2003), Operations management: critical perspectives on business management, Routledge: London.

Li, S. and Lin, B. (2006), "Accessing information sharing and information quality in supply chain management”, Decision Support Systems, 42(3), pp. 1641-1656.

Luftman, J. (1998), “Enablers \& Inhibitors", Information Week, vol. 14, pp. 283-286.

Luftman, J. and Brier, T. (1999), "Achieving and sustaining business-IT alignment", California Management Review, vol. 42, no. 1, pp. 109-122.

Lummus, R.R. and Vokurka, R.J. (1999), "Managing the demand chain through managing the information flow: Capturing 'moments of information' ", Production and Inventory Management Journal, vol. 40, no. 1, p. 16.

Maku, T.C., Collins, T.R. and Beruvides, M.G. (2005), "The Impact of Human Interaction on Supply Chain Management Practices", Performance Improvement, vol. 44, no. 7, p. 26.

Marquez, A.C. and Blanchar, C. (2006), "A Decision Support System for evaluating operations investments in high-technology business", Decision Support Systems, vol. 41, no. 2, p. 472.

Maskell, B.H. (1991), Performance measurement for world class manufacturing, Cambridge, MA, Productivity Press. 
Matthyssens, P. and Vandenbempt, K. (2008), "Moving from basic offerings to value-added solutions: Strategies, barriers and alignment", Industrial Marketing Management, vol. 37, iss. 3, p. 316.

McAdam, R. and Brown, L. (2001), "Strategic alignment and the supply chain for the steel stockholder sector: an exploratory case study analysis", Supply Chain Management: and International Journal, vol. 6, no. 2, pp. 83-94.

Melnyk, S.A., Stewart, D.M. and Swink, M. (2004), "Metrics and performance measurement in operations management: dealing with the metrics maze", Journal of Operations Management, vol. 22 , no. 3, p. 209.

Miles, M.B. and Huberman, M.A. (1994), Qualitative Data Analysis, SAGE, Thousand Oaks, CA

Monczka, R.M., Handfield, R.B, Giuipero, L.C. and Pattersson, J.L. (2009), Purchasing and supply chain management, South Western.

Morash, E.A. and Clinton, S.R. (1998), "Supply chain integration: customer value through collaborate closeness versus operational excellence", Journal of Marketing Theory \& Practice, vol. 6, no. 4, pp. 104-120.

Morash, E.A., Droge, C.L.M. and Vickery, S.K. (1996), "Boundary spanning interfaces between logistics, production, marketing and new product development", International Journal of Physical Distribution \& Logistic Management, vol. 26, No. 8, pp. 43-62.

Morgan, C. (2004), "Structure, speed and salience: performance measurement in the supply chain", Business Process Management Journal, vol. 10, no. 5, p. 522.

Muratoglu, K. (2008), "Performance Measurement of Supply Chain Via Balanced Scorecard: The Case of a Brewing Group", The Business Review, vol. 10, iss. 1, pp. 330-337.

Neely, A. (Editor) (2002), Business performance measurement: theory and practice, Cambridge University Press, Cambridge.

Nadler, D. and Tushman, M. (1988), Strategic organization design: concepts, tools and processes, Scott, Foresman.

Nichol, R.L. (1992), "Get Middle Managers Involved in the Planning Process", The Journal of Business Strategy, vol. 13, no. 3, p. 26.

O’Mara, C.E., Hyland, P.W. and Chapman, R.L. (1998), "Performance Measurement and strategic change", Managing Service Quality, vol. 8, no. 3, pp. 178-182.

O'Leary-Kelly, S.W.O. and Flores, B.E., (2002), "The integration of manufacturing and marketing/sales decisions: impact on organizational performance", Journal of Operations Management, vol. 20, pp. 221-240.

Osterlund, J. and Loven, E. (2005), "Information versus inertia: a model for product change with low inertia", Systems Research and Behavioral Science, vol. 22, no. 6, p. 547.

Othman, R. and Ghani, R.A., (2008), "Supply chain management and suppliers' HRM practice”, Supply Chain Management: an International Journal, vol. 13, iss. 4, pp. 259-262.

Pagell, M. (2004), " Understanding the factors that enable and inhibit the integration of operations and logistics", Journal of Operations Management, vol. 22, iss. 5, p. 459.

Petersen, K.J., Handfield, R.B. and Ragatz, G.L. (2005), "Supplier integration into new product development: coordinating product, process and supply chain design", Journal of Operations Management, vol. 23, no. 3, 4, p. 371. 
Pollalis, Y.A. (2003), "Patterns of co-alignment in information-intensive organizations: business performance through integration strategies", International Journal of Information Management, vol. 23 , no. 6 , p. 469.

Porter, M. E. (1985), Competitive Advantage: Creating and Sustaining Superior Performance, Free press, a division of Macmillan Inc.

Powell, T.C. (1992), "Organizational alignment as competitive advantage", Strategic Management Journal, vol. 13, no. 2, pp. 119-134.

Powers, V. (1996), "Benchmarking study illustrates how best-in-class achieve alignment, communicate change", Communication World, vol. 14, iss. 1, p. 30.

Quinn, J. (1993), The intelligent enterprise, The Free Press, New York.

Rappaport, A. (1987), "Linking Competitive Strategy and Shareholder Value Analysis", Journal of Business Strategy, vol. 7, no. 4, p. 58.

Reichhart, A, and Holweg, M. (2007), "Creating the customer-responsive supply chain: a reconciliation of concepts", International Journal of Operations \& Production Management, vol. 27 , iss. 11 , pp. 1144-1172.

Rich, N. and Hines, P. (1997), "Supply-chain management and time-based competition: the role of the supplier association", International Journal of Physical Distribution \& Logistics Management, vol. 27, no. 3/4, p. 210.

Robertson, T. S. and Barich, H. (1992), "A Successful Approach to Segmenting Industrial Markets", Planning Review, vol. 20, no. 6, p. 4.

Robson, I. (2004), "From process measurement to performance improvement", Business Process Management Journal, vol. 10, No. 5, p. 510.

Rodrigues, A.M., Stank, T.P. and Lynch, D.F. (2004), "Linking Strategy, Structure, Process, and Performance in Integrated Logistics", Journal of Business Logistics, vol. 25, no. 2, p. 65.

Sabath, R. and Whipple, J.M. (2004), "Using the Customer/product Action Matrix to Enhance Internal Collaboration", Journal of Business Logistics, vol. 25, no. 2, p. 1.

Sahay, B.S. (2003), "Understanding trust in supply chain relationships", Industrial Management + Data Systems, vol. 103, no. 8/9, p. 553.

Sahin, F. and Robinson, E.P. (2002), "Flow coordination and information sharing in supply chains: Review, implications, and directions for future research", Decision Sciences, vol. 33, no. 4, p. 505 .

Sandberg, E. (2007), "Logistics collaboration in supply chains: practice vs. theory", International Journal of Logistics Management, vol. 18, iss. 2, pp. 274-293.

Schmenner, R.W. and Vollmann, T.E. (1994), "Performance measures: gaps, false alarms and the 'usual suspects' ", International Journal of Operations \& Production Management, vol. 14, no. 12 , pp. 58-69.

Scott, C. and Westbrook, R. (1991), "New Strategic Tools for Supply Chain Management", International Journal of Physical Distribution \& Logistics Management, vol. 21, no. 1, p. 23.

Sha, D.Y., Chen, P.K. and Chen, Y.H. (2008), "The strategic fit of supply chain integration in the TFT-LCD industry", Supply Chain Management: an International Journal, vol. 13, iss. 5, pp. 339-342. 
Simatupang, T.M. and Sridharan, R. (2004), "Benchmarking supply chain collaboration: An empirical study”, Benchmarking, vol. 11, no. 5, p. 484.

Skinner, W. (1969), "Manufacturing: missing link in corporate strategy", Harvard Business Review, May-June, pp. 136-145.

Slater, S.F. and Narver, J.C. (1994), "Market orientation, customer value, and superior performance", Business Horizons, vol. 37, no. 2, p. 22.

Soosay, C.A., Hyland, P.W. and Ferrer, M. (2008), "Supply chain collaboration: capabilities for continuous innovation", Supply Chain Management: an International Journal, 13(2), pp. 160169.

Srivastava, R.K., Shervani, T.A. and Fahey, L. (1999), "Marketing, business processes, and shareholder value: An organizationally embedded view of marketing activities and the discipline of marketing", Journal of Marketing, vol. 63, p. 168.

Starbuck, W.H. (2006), The production of knowledge, Oxford University Press, Oxford.

Storbacka, K. and Nenonen, S. (2009), "Customer relationships and the heterogeneity of firm performance", The Journal of Business \& Industrial Marketing, vol. 24, iss. 5/6, pp. 360-372.

Storey, J., Emberson, C. and Reade, D. (2005), “The barriers to customer responsive supply chain management", International Journal of Operations \& Production Management, vol. 25, no. 3/4, p. 242.

Sussman, G.I., Dean Jr., and J.W. (1992), Development of a model for predicting design for manufacturability effectiveness. In: Sussman, G.I. (Ed.), Integrating Design and Manufacturing for Competitive Advantage. Oxford University Press, New York, pp. 207-227.

Tamas, M. (2000), "Mismatched strategies the weak link in the supply chain?" Supply Chain Management: and International Journal, vol. 5, no. 4, pp. 171-175.

Tarn, J.M., Yen, D.C. and Beaumont, M. (2002), "Exploring the rationales for ERP and SCM integration", Industrial Management + Data Systems, vol. 102, no. 1/2, p. 26.

Thompson, J. (1967), Organizations in Action, McGraw-Hill, New York, NY.

Toni, De A. and Tonchia, S. (1996), "Lean Organization, management by process and performance measurement", International Journal of Operations \& Production Management vol. 16 (no.2), pp. 221-236.

Tracey, M., Lim, J. and Vonderembse, M.A. (2005), "The impact of supply-chain management capabilities on business performance", Supply Chain Management, vol. 10, no. 3/4, p. 179.

Tranfield, D., Denyer, D. and Smart, P. (2003), Towards a methodology for developing evidenceinformed management knowledge by means of systematic review, British Journal of Management, vol. 14, pp. 207-222.

Tsinopoulos, C. and Bell, K. (2010), "Supply chain integration systems by small engineering to order companies: The challenge of implementation", Journal of Manufacturing Technology Management, vol. 21, iss. 1, pp. 50-62.

Van Hoek, R.I. and Mitchell, A.J. (2006), "The challenge of internal misalignment", International Journal of Logistics: Research and Applications, vol. 9 no. 3, pp. 269-281.

Venkatraman, N. (1989), "The concept of fit in strategy research: toward verbal and statistical correspondence", The Academy of Management Review, 14(3), pp. 423-444. 
Waggoner, D.B., Neely, A.D. and Kennerley, M.P. (1999), "The forces that shape organisational performance measurement systems: An interdisciplinary review", International Journal of Production Economics, vol. 60-61, pp. 53-60.

Wheelwright, S.C. (1984), "Manufacturing strategy: defining the missing link", Strategy Management Journal, vol. 5, no. 1, pp. 77-91.

Wheelwright, S.C. and Clark, K.B. (1992), Revolutionising product development, Free Press, New York, NY.

Wilcox, M. and Bourne, M. (2003), "Predicting performance", Management Decision, Vol. 41, no. 8, p. 806.

Woodruff, R.B. (1997), "Customer value: The next source for competitive advantage", Academy of Marketing Science Journal, vol. 25, no. 2, p. 139.

Yasin, M.M., Bayes, P.E. and Czuchry, A.J. (2005), "The Changing Role of Accounting in Supporting the Quality and Customer Goals of Organizations: An Open System Perspective", International Journal of Management, vol. 22, no. 3, p. 323. 